\title{
Studying alcohol use disorder using Drosophila melanogaster in the era of 'Big Data'
}

\author{
Gregory L. Engel ${ }^{1}$, Kreager Taber ${ }^{2}$, Elizabeth Vinton ${ }^{2}$ and Amanda J. Crocker ${ }^{2 *}$ (1)
}

\begin{abstract}
Our understanding of the networks of genes and protein functions involved in Alcohol Use Disorder (AUD) remains incomplete, as do the mechanisms by which these networks lead to AUD phenotypes. The fruit fly (Drosophila melanogaster) is an efficient model for functional and mechanistic characterization of the genes involved in alcohol behavior. The fly offers many advantages as a model organism for investigating the molecular and cellular mechanisms of alcohol-related behaviors, and for understanding the underlying neural circuitry driving behaviors, such as locomotor stimulation, sedation, tolerance, and appetitive (reward) learning and memory. Fly researchers are able to use an extensive variety of tools for functional characterization of gene products. To understand how the fly can guide our understanding of AUD in the era of Big Data we will explore these tools, and review some of the gene networks identified in the fly through their use, including chromatin-remodeling, glial, cellular stress, and innate immunity genes. These networks hold great potential as translational drug targets, making it prudent to conduct further research into how these gene mechanisms are involved in alcohol behavior.
\end{abstract}

Keywords: Alcohol behavior, Drosophila, Fruit fly, Next-generation sequencing, Animal model

\section{Background}

As of 2015, Alcohol Use Disorder (AUD) directly affected over 15 million people in the United States. Its social, financial, and medical repercussions affect countless others [1]. The Center for Disease Control estimates that alcohol use is a contributing factor in over 80,000 deaths annually [2]. The National Epidemiologic Survey on Alcohol and Related Conditions (NESARC) recently found that AUD diagnoses reach as high as $36.7 \%$ in individuals 30-44 years old [3]. While the impact of AUD is clearly wide-ranging, the disorder remains poorly understood. Developing an understanding of the underlying biological mechanisms driving AUD is important for the development of novel treatments.

AUD is a complex phenotype characterized in the Diagnostic and Statistical Manual of Mental Disorders, 5th Edition (DSM-5) by multiple diagnostic criteria including alcohol consumption, craving, dependence,

\footnotetext{
${ }^{*}$ Correspondence: acrocker@middlebury.edu

2 Program in Neuroscience, Middlebury College, Middlebury, VT 05753, USA

Full list of author information is available at the end of the article
}

tolerance, withdrawal, and/or continued consumption despite negative consequences [4]. Both environmental and genetic factors play a role in each criterion and in the development of AUD [1]. Twin studies have shown heritability runs from 40 to $60 \%$ [5-8]. Differences exist in the cellular structure and gene expression in the brains of AUD patients [9-12] when compared to non-AUD control subjects. Whether these differences are purely the result of alcohol consumption, or due to preexisting differences in underlying structure, is unknown.

Strides have been made to understand the role that genetics play in AUD. In recent decades research has moved away from one-gene models towards models that encompass multiple contributing gene effects $[1,5,13$, 14]. This new understanding was facilitated by genomewide association studies (GWAS) coupled with the fine genome mapping tools now available, and by transcriptional studies [14, 15]. However, human population studies are hampered by the long time course of AUD's development and a patient's unknown environmental factors. Because of this animal models of AUD are critical to furthering our understanding of the disorder. Modeling of AUD phenotypes across model organisms with 
well-characterized genomes has identified gene-networks that have provided novel insights [16-20].

In this review we will focus on lessons learned from genomic studies of alcohol behavior in Drosophila melanogaster (henceforth, the fly) and their implications for AUD. Flies share approximately $75 \%$ homology with the human genome in disease-causing genes [21-23] and representation of all major gene families found in humans, making them a cost-effective model for studying the role of genes and gene products in human disorders [24]. Flies also possess a smaller and less complex genome, as well as a smaller, more characterized nervous system that coordinates a broad repertoire of behaviors [25]. Because of this it is relatively easy to validate the behavioral roles of candidate genes, putting the fly model at the forefront of genomic studies of AUD. Additionally, the fly offers the potential to develop a mechanistic understanding of the genes involved in AUD phenotypes. To highlight the advantages of the fly for studies of AUD we will describe the techniques used to study alcohol genetics in flies and the specific gene networks involved in alcohol behavior that have already been identified there.

\section{Part 1: Techniques for studying alcohol genetics in flies}

\section{Alcohol behaviors in the fly}

Like humans, flies have a robust evolutionary relationship with alcohol. They hold a naturally evolved preference for laying eggs on fermenting fruit, and show many of the defining characteristics of AUD [24, 26, 27]. Compared to humans flies show increased resistance to many of the effects of different primary alcohols, including ethanol, the least toxic alcohol in mammals and the fly [28]. However, both humans and flies show natural variations in sensitivity to different effects of alcohol, including its stimulating effect at low doses, and its sedative effect at high doses [29, 30]. Similar to mammals, flies develop both metabolic and functional tolerances to ethanol, and show evidence of reinstatement after withdrawal [27, 30, 31]. Additionally, flies show robust preference learning when alcohol is paired with either olfactory, gustatory, and/or visual cues [32].

While the fly is well-suited for AUD studies, it is worth noting that to date flies only display a subset of phenotypes associated with the disorder. The most widely studied are alcohol sensitivity, alcohol tolerance, and preference learning.

\section{Alcohol sensitivity assays}

Alcohol in low quantities produces stimulatory effects in both humans and flies [33-36]. At larger quantities it produces nervous system depression [28, 33,
37]. Sensitivity to these effects in humans is one of the strongest predictors of AUD; Schuckit et al. tracked men for 25 years and determined that baseline alcohol sensitivity was the greatest predictor of AUD [38]. Their findings suggested that those who were resistant to alcohol effects would require greater quantities of alcohol in order to experience the positive feelings associated with alcohol and thus were risking greater alcohol induced changes [39].

In the fly there are a number of ways to assess alcohol sensitivity phenotypes (Table 1 ). One of the earliest assays, the "inebriometer" $[24,40]$, assessed the disinhibitory effects of alcohol on large fly populations. Flies exposed to increasing concentrations of alcohol in a large vertical tube would gradually fall due to the loss of postural control and sedation (for a more detailed description see [24]) [41]. Flies will also become sedated following exposure to long-periods of low concentration alcohol vapor. The inebriometer assay has been refined to quantify subtle behavioral changes due to alcohol exposure, and to increase the efficiency of screening large numbers of genotypes at once. This upgraded assay is known as the "booz-o-mat" [35]. In it, flies are placed in horizontal tubes through which humidified alcohol vapor is passed. By placing the apparatus horizontally any pre-existing motor deficits in the flies are minimized as they no longer need to climb vertically or hold onto supports. This assay also provides tighter control over alcohol concentrations

\begin{tabular}{|c|c|}
\hline Term: & Definition \\
\hline ChIP-seq & Chromatin immunoprecipitation sequencing \\
\hline GWAS & $\begin{array}{l}\text { Genome wide association studies (also known as WGA- } \\
\text { whole genome association) }\end{array}$ \\
\hline MB & $\begin{array}{l}\text { Mushroom body; an important neural center in flies; } \\
\text { involved in olfaction and olfactory memory formation }\end{array}$ \\
\hline NGS & $\begin{array}{l}\text { Next generation sequencing (massive parallel sequenc- } \\
\text { ing) }\end{array}$ \\
\hline RNA-seq & RNA sequencing (whole genome RNA sequencing) \\
\hline SNP & Single nucleotide polymorphism \\
\hline Wildtype & $\begin{array}{l}\text { Aa model strain of organism fly with no induced muta- } \\
\text { tions }\end{array}$ \\
\hline RNAi & $\begin{array}{l}\text { Short hairpin RNA used to target RNA for degradation. } \\
\text { Used to knockdown expression of genes }\end{array}$ \\
\hline \multicolumn{2}{|c|}{ Behavioral assays: terms } \\
\hline booz-o-mat & Aa horizontal assay for intoxicating flies \\
\hline $\begin{array}{l}\text { Inebriom- } \\
\text { eter }\end{array}$ & Aa vertical assay for intoxicating flies \\
\hline CAFE & Ccapillary feeding assay \\
\hline PER & $\begin{array}{l}\text { Pproboscis extension reflex; used to study alcohol's } \\
\text { appetitive properties }\end{array}$ \\
\hline
\end{tabular}


and finer analyses of fly behavior during and after alcohol exposure [35]. For example, in the booz-o-mat the stimulant effect of low doses of alcohol becomes apparent as an increase in locomotor behavior, as does the eventual decrease in activity (until full sedation) seen with higher levels of alcohol [35]. The sedative inebriation of flies in this assay reflects high levels of inebriation in the same way that the loss of righting reflex (LORR) does in mice [39]. Another measure of alcohol sensitivity is time to recovery following sedation. Flies are exposed to ethanol vapor of a given concentration (e.g. $35 \%$ ethanol of a cotton plug) until all flies are sedated, and then the time to recovery is recorded [19, 42].

Alcohol sensitivity is indicated by a population mean elution time (MET) in the inebriometer, or time to $50 \%$ sedated or recovered in sedation assays [19, 41-43]. The low cost and high-throughput nature of these assays make them very powerful for screening large numbers of flies in a relatively short period. Results from these assays demonstrate that flies may be evolutionarily adapted to prefer alcohol-rich environments and demonstrate robust behavioral responses to alcohol, and that these responses can change due to genetic and environmental manipulations [16, 44-46].

\section{Alcohol tolerance assays}

Tolerance, the consumption of larger quantities of alcohol to achieve the same response or exhibiting a lower response to the same quantity of alcohol, is a defining characteristic of AUD. In many human studies alcohol consumption rates are used as the defining AUD phenotype for gene identification [9]. Flies can also develop the three types of tolerance to alcohol [24, 26, 28]: acute tolerance (a model for binge drinking), rapid tolerance (tolerance following metabolism of a single dose of alcohol), and chronic tolerance (developed from repeated alcohol exposure) [47]. The fly has been used to study these modes of tolerance in many ways. Findings include that larvae grown on media containing alcohol prefer higher alcohol concentrations as adults [48], adult flies who have consumed alcohol will consume alcohol in greater quantities during a second exposure [27, 47], and adult flies exposed to alcohol vapor are more resistant to alcohol's behavioral effects upon second exposure [35, 47, 49].

The same behavioral assays described above for studying sensitivity are also used when looking at tolerance. In the inebriometer, higher METs are seen on the second exposure to the same concentration of alcohol vapor and recovery time from sedation decreases $[43,45,50]$. Studies performed using the booze-o-mat have also shown the development of rapid tolerance, particularly to stimulatory effects of alcohol upon second exposure [35, 51].

Consumption assays are also well-suited for studying alcohol tolerance. Long-term exposure is modeled through raising flies on alcohol-infused food [48, 52]. This type of assay not only models chronic tolerance but also is used to model fetal alcohol syndrome [53]. Other consumption-based assays involve short term access to alcohol-infused food [27, 54]. The capillary feeder (CAFE) assay can be used to quantify the amount of a liquid consumed by a population of flies in a given period. In this assay the amount of fluid consumed from filled capillaries is measured and compared to an evaporation control [54]. Alcohol exposure results in flies increasing their consumption of alcohol in this assay [44]. One notable precondition to this assay's use is that in order for flies to drink to the relevant blood alcohol levels, they must first be starved prior to being placed in the CAFE assay [27, 44]. This induces a stress which is important to note in any discussion of gene networks involved in alcohol consumption in the fly [55]. Variations of the CAFE assay can create a choice between two capillaries containing different stimuli. This has been used to study alcohol tolerance as well as preference in the fly [44]. Flies will prefer to drink alcohol over water, and prefer to consume more alcohol following prior exposure to alcohol [27]. Flies show adaptation to both the negative and positive aspects of alcohol consumption, facilitating increased alcohol intake.

\section{Alcohol association preference assays}

While the assays described above measure specific alcohol-induced motor or gustatory behavior, many others have been developed based on well-characterized learning and memory assays to assess the encoding of alcohol's negative and positive valences [32]. The proboscis extension reflex (PER) assay models short term memory of gustatory cues [56]. As flies extend their proboscii in response to different nutrients, the rate of extension indicates learned associations with appetitive or aversive substances [57]. Like the CAFE assay described above, flies must also be starved prior to performing the PER assay, complicating its interpretation.

The most commonly used alcohol preference assay is based on the classic olfactory T-maze used in fly learning and memory studies. Flies are exposed to inebriating concentrations of alcohol while also exposed to a neutral odor [32]. Because the fly increases its proximity to appetitive odors, its movement towards or away from alcoholpaired odors indicates whether the fly perceives alcohol intoxication as appetitive or aversive, respectively [24]. Initially, alcohol induces an aversion to an odor paired 
with it, but later this reverses so the paired stimulus is preferred [32].

Recent work has detailed conditioned associations of alcohol at different concentrations and exposure times [58]. It has shown that low levels of alcohol do not form appetitive long-term cued memories, whereas moderate levels of alcohol form appetitive memories and these memories are enhanced by multiple cue pairings [58]. At high levels of alcohol exposure flies fail to form long-term appetitive memories and in some cases form long-term aversive memories, though there is evidence of short term attraction [58]. From this work it is clear that at different time points, and at different concentrations of alcohol, behavioral responses will vary. This work also points out that the most relevant alcohol concentrations, if one wants to model alcohol's rewarding and cueinduced addictive qualities in the fly, are moderate doses around $8 \mathrm{mM}$ spaced over multiple days, or between 6 and $8 \mathrm{mM}$ trained on a single day with multiple exposures [58].

\section{Variations on alcohol conditioned learning assays}

It is worth discussing two studies that used notably different methods to assay alcohol conditioned preference. Both assays include an element of stress, which is often neglected in conceptualizing alcohol behavior in the fly. Flies are known to experience stress, which changes their behavior in ways similar to mammals [59]. Stress is a major contributor to AUD, and particularly to relapse behavior [60]. These studies may provide novel insights into how ancient stress pathways interact with alcohol behavior, particularly with tolerance and reward.

Flies have evolved a mechanism to increase alcohol consumption to protect their larvae from parasitic wasps $[61,62]$. Exposure to these wasps drives females to lay eggs on food sources with higher alcohol concentrations. Naïve flies prefer food with $3 \%$ alcohol for laying, whereas $6-12 \%$ is preferred in flies exposed to wasps $[56,62]$. This level of alcohol is considered toxic due to the reduced viability of exposed offspring, but is effective in reducing wasp infection in the fly larvae $[61,63]$. This demonstrates a strong drive to attain alcohol in wasp-exposed flies, even at toxic levels. This behavior is observed even after the wasps no longer pose a threat $[62,63]$. However, the cues that drive the female to seek higher alcohol concentrations and the underlying transcriptional changes that facilitate retention of this behavior remains poorly understood. The stress of wasp exposure may be analogous to the stress of starvation necessary for flies to consume higher alcohol in the CAFE assay. Known regulators of fly anxiety-like behavior, including GABA, dopamine, serotonin, and octopamine (norepinephrine homologue) signaling are important in alcohol behavior [59, 64-69].

Another study linking alcohol intake to stress demonstrated that male flies who fail to copulate with a female increase their alcohol intake [70]. The authors argued that the reward of copulation could supplant the rewarding nature of alcohol. Another interpretation of this study is that failed copulation increases stress, leading to increased alcohol consumption. Work by Winbush et al. looking at transcriptional changes following $30 \mathrm{~min}$ of courtship (no copulation) supports the notion that courtship rejection is stressful [71]. In addition, Devineni and Heberlein demonstrated that flies will overcome aversive signals to seek alcohol, and these aversive signals also induce behavioral stress phenotypes such as increased wall following [27, 59]. Not only is there an increase in the behavioral stress response, but transcriptional changes following aversive stimuli indicate an increase in cellular stress response genes [72]. Other stressors are known to effect alcohol responses across species. One such stressor is sleep deprivation [73, 74]. Changes in sleep patterns often occur following environmental stressors, and these changes may also influence alcohol behavior. Recent work demonstrated overlapping pathways between alcohol sensitivity and sleep deprivation sensitivity through the adenosine A1 receptor [74].

\section{Genomics and transcriptomics}

Beyond serving as an ideal model for alcohol behavior, the genetics of the fly is highly tractable. Over 600 different fly genomes are available for analysis (see section for wildtype populations of flies in Table 2) and over 4.8 million single nucleotide polymorphisms (SNPs) have been identified in the fly genome (dbSNP build 149) [75-78]. Together, the level of fine mapping and the availability of fully sequenced large populations of flies have made the fly an ideal model to study behaviors with complex genetic underpinnings.

The fly can easily be used to validate gene mechanisms in human disorders. A prime example of this is in the validation of a SNP in the intronic region of the human AUTS2 gene. This SNP was found in a GWAS study looking at alcohol consumption [79]. The AUTS2 gene was also identified when comparing a mouse line bred for high alcohol preference (HAP1) with low alcohol preferring mice (LAP1) [79, 80]. Mechanistic validation was demonstrated in the fly through reduced expression of the fly homolog tay, resulting in a blunted sensitivity to alcohol [79]. Tay, a negative regulator of the Epidermal Growth Factor Receptor (EGFR) pathway, has been implicated in a number of studies of alcohol behavior in the fly $[16,44,45,49,81,82]$ as well as mammalian 
Table 2 Tools and resources available to study AUD in the fly

\begin{tabular}{|c|c|c|}
\hline \multicolumn{2}{|l|}{ Fly resources } & \multirow[t]{2}{*}{ Refs } \\
\hline Drosophila network resources & https://wiki.flybase.org/wiki/FlyBase:Drosophila_Network_Resources & \\
\hline Flybase & http://flybase.org/ & [178] \\
\hline Bloomington Stock center & https://bdsc.indiana.edu/index.html & \\
\hline Alliance of genome resources & https://www.alliancegenome.org/ & \\
\hline \multicolumn{3}{|l|}{ Wildtype populations of flies } \\
\hline Drosophila genetic reference panel (DGRP) & http://dgrp2.gnets.ncsu.edu/ & {$[77]$} \\
\hline Drosophila synthetic population resource (DSRP) & http://wfitch.bio.uci.edu/ dspr/index.html & {$[75]$} \\
\hline Global diversity lines & http://www.johnpool.net/genomes.html & {$[76]$} \\
\hline \multicolumn{3}{|l|}{ Genetic tools for cell-type specific next-generation sequencing } \\
\hline INTACT & Nuclear purification & [117] \\
\hline TRAP & Translating Ribosomal Affinity Purification & {$[114,115]$} \\
\hline TU or EC tagging & Labels RNA following feeding of 4-thiouracil or 5-ethynylcytosine & {$[179,180]$} \\
\hline CAST-ChIP & & [118] \\
\hline DamlD & Methylation-based chromatin profiling & [181] \\
\hline \multicolumn{3}{|l|}{ Relevant collections of fly strains for behavioral validation } \\
\hline Vienna RNAi lines & & [182] \\
\hline Transgenic RNAi project & & [183] \\
\hline FlyLight & https://www.janelia.org/project-team/flylight & [184] \\
\hline Gene disruption project & $\begin{array}{l}\text { MiMIC and CRIMIC lines } \\
\text { http://flypush.imgen.bcm.tmc.edu/pscreen/about.html }\end{array}$ & {$[86]$} \\
\hline \multicolumn{3}{|l|}{ Relevant drosophila transcriptional data sets } \\
\hline Updated mapping of Drosophila sequence read archive & GEO Series GSE117217 & \\
\hline Single-cell whole brain & GEO Series GSE107451 & \\
\hline Kenyon cells & GEO Series GSE115718 & \\
\hline Kenyon cells & GEO Series GSE1 19629 & \\
\hline Kenyon cells and subset of MBONs & GEO Series GSE74989 & \\
\hline Mating behavior & GEO Series GSE104706 & \\
\hline Antennal lobe & GEO Series GSE99545 & \\
\hline CREB RNA binding & $\begin{array}{l}\text { GEO Series GSE59611 } \\
\text { GEO Series GSE73386 }\end{array}$ & \\
\hline Ethanol exposure RNA expression & $\begin{array}{l}\text { GEO Series GSE77792 } \\
\text { GEO Series GSE89137 } \\
\text { GEO Series GSE48449 }\end{array}$ & \\
\hline \multicolumn{3}{|l|}{ Gene network analysis sites } \\
\hline modENCODE & http://www.modencode.org/ & [185] \\
\hline SCENIC & http://scenic.aertslab.org & [186] \\
\hline AmiGO 2 & http://amigo.geneontology.org/amigo/ & {$[187,188]$} \\
\hline DAVID bioinformatics database & https://david.ncifcrf.gov/ & {$[189,190]$} \\
\hline MEME-ChiP & http://meme-suite.org/index.html & [191] \\
\hline Weighted gene co-expression network & https://horvath.genetics.ucla.edu/html/CoexpressionNetwork/ & {$[119,192]$} \\
\hline Reactome & https://reactome.org/ & [193] \\
\hline Cytoscape & https://cytoscape.org/ & [194] \\
\hline Geneweaver 2 & https://beta.geneweaver.org/ & [195] \\
\hline
\end{tabular}

studies (reviewed in [83]). Further mechanistic validation studies of mammalian genes implicated in AUD in the fly will be enhanced by large scale efforts underway, including the determination of the fly brain connectome [84], identification of each neuron molecularly and cellularly [85], creation of mutations in every gene in the fly genome [86], and identification of the transcriptional landscape across time, anatomical structures, and experimental conditions [72, 87-90]. 
The fly is also ideal for use in GWAS studies, where it allows for tight control over environmental factors. The Drosophila Genetics Reference Panel (DGRP) and, more recently, the Drosophila Synthetic Population Resource (DSPR) are comprised of inbred fly lines derived from wildtype flies over many generations [75, 77]. The DGRP consists of approximately 200 lines whose genomes have been sequenced [91]. Transcriptional information is now available for a subset of those lines [44, 77, 89, 91]. Further refinement of the DGRP is possible through an advanced intercross scheme that puts a diverse subset of DGRP lines through a mating routine which refines the areas associated with SNPs [44]. Both the DGRP lines and the advanced intercross lines have been instrumental in identifying gene networks associated with sleep, lifespan, olfactory behavior, and alcohol sensitivity and tolerance [16, 92-96].

GWAS studies have limitations, including the inability to predict transcriptional changes in response to alcohol exposure and chronic use [9, 15, 17, 80, 97]. Transcriptome analysis has shed light on this research area. Microarrays and whole transcriptome shotgun sequencing (RNA-seq) are the tools that have been most commonly used to perform transcriptome analysis (techniques reviewed by [98]). While microarray technology has come a long way over the last two decades, it is still restricted by the quantity of probes that can be put on a chip and by probe choice [98]. That said, RNA microarrays are still a particularly cost effective method to characterize responses to alcohol within specific brain regions, cell-types, and across species [10, 43, 49, 64, 80, 98-101]. In both RNA-seq and microarrays, sample quality is critical; particularly in microarrays due to their dependence on probes for transcript identification [98].

RNA-seq methods are now preferred over microarrays for whole genome profiling, as their greatest strength is the ability to uncover a range of different transcriptome complexities without reliance on probes. This is particularly useful when considering potential alternative splice forms and non-coding RNAs associated with AUD [102104]. Alternative splice forms have been shown to play a role in alcohol behavior in humans and flies [105-107]. It has been established that alternative splicing of the slowpoke gene mediates fly alcohol tolerance [40, 108] and the full impact of alternative splicing events is only now being appreciated. Signor and Nuzhdin recently made available a comprehensive data set from a long-read RNA-seq study [107]. This work showed that changes in exon expression due to alcohol presentation build the longer animals are exposed [107]. Limited alternative splicing in response to alcohol (meaning similar expression of gene but alternative exon expression) was shown, but changes in the rank order of the presence of specific exons changed based on alcohol presentation [107].

Recent human transcriptome studies have shown the impact of long-term alcohol use on subtle transcriptional changes in multiple brain regions, including the nucleus accumbens, hippocampus, and prefrontal cortex [9, 97, 99, 109]. These areas are important for reward, learning, and executive functioning and are strongly implicated in AUD [65]. Within the hippocampus RNA-seq work has identified potential neural adaption mechanisms important in alcohol's addictive properties [97, 109]. Recent work has also shown evidence of alternative gene splicing across different brain regions, emphasizing the need for more region-specific and cell-specific studies [110].

One powerful technique that allows investigation of region- and cell-specific transcriptional changes in the fly is the GAL4/UAS system [111-113]. This technique allows the yeast GAL4 transcription factor to be expressed under the control of a specific gene promoter or enhancer. The GAL4 transcription factor binds to an upstream activating sequence (UAS), which leads to the expression of a downstream gene [111]. Large collections of GAL4 and UAS fly lines exist (see Table 2). Using the GAL4/UAS system fly geneticists can express almost any protein in any cell type, allowing cells to be identified and sorted based on fluorescent protein expression or tagged proteins. These tags can be used to perform cell-type specific transcriptional analysis by a variety of techniques, including translating ribosome affinity purification (TRAP) $[114,115]$, isolation of nuclei tagged in specific cell types (INTACT), and chromatin affinity purification (CAST-ChIP) [116-118] (see Table 2 for additional tags).

These transcriptional analysis techniques can distinguish transcript changes due to stimuli versus those due to network regulation. Many genes work within networks where a change in expression in one gene may actually reflect a change in an entire network of genes that share common regulators. Network analysis can find hubs in gene networks which can point to common regulatory networks (see weighted gene coexpression network analysis (WGCNA)) [119]. It can also identify novel regulatory mechanisms including epigenetic modifications that cause coordinated gene expression changes. These epigenetic modifications play a role in alcohol behavior across species [19, 120]. Modern sequencing techniques like ChIP-seq have greatly increased our ability to directly study the epigenetic changes that occur during alcohol behavior. This method utilizes antibodies for specific transcription factors or chromatin modifiers to tag DNA where transcription is potentially occurring [121].

Collectively, these genomic and transcriptomic techniques have provided information on both the underlying 
genomic landscape as well as changes to this landscape that drive alcohol behavior in the fly.

\section{Part 2: Gene networks implicated in alcohol behavior in the fly}

Genomic and transcriptomic studies of alcohol behavior in the fly have provided insight not only into the individual genes that play a role, but also into their functional networks. Over the last 20 years our understanding of how these networks fit into the behavioral mechanisms of alcohol sensitivity, tolerance, and conditioned preference learning has greatly expanded. This is partly due to increased gene annotation, increased availability of data sets, and public databases that compare across studies and species (see Table 2 for a list of relevant datasets). These genomic survey studies have reinforced the findings of earlier forward genetic screens that identified single genes involved in alcohol behavior (see reviews [24, $31,52])$ and are now shedding light on how these genes act in the networks identified more recently [82, 106, 122].

Morozova et al. have demonstrated the involvement of networks regulating metabolic enzymatic activity, oxidative stress, glial functioning, nervous system functioning, metabolism, chromatin modification, cytoskeleton dynamics, and immune response genes in alcohol behavior $[16,43,45,53,123]$. In addition, they found that distinct genes affect alcohol sensitivity and alcohol tolerance [16]. Extensive review of the role metabolic enzymes and neuronal signaling genes play in alcohol behavior can be found elsewhere $[31,52,124]$. We will now highlight gene networks identified in the fly that have received less attention and will be crucial in understanding alcohol behavior across species [18, 100, 125-128].

\section{Chromatin remodeling genes}

Chromatin remodeling in the form of histone acetylation, deacetylation, methylation, and demethylation all play a role in transcription by modulating access to the DNA. Genes coding for chromatin remodeling enzymes are important in the discussion of gene networks, not only because they have been implicated through gene network analysis in alcohol behavior across species [19, 51, 97, $109,120,129-131]$, but because they possess the capability to coordinate gene networks. Histone acetylation via histone acetyltransferases (HATs) can provide access to DNA in a coordinated and long-lasting fashion, resulting in a network of transcripts becoming upregulated, while histone deacetylases (HDACs) mediate the opposite function.

Ghezzi et al. exploited the coordinating functions of HATs and HDACs using ChIP-seq methods to probe for histone acetylation changes due to alcohol tolerance (both benzyl and ethyl alcohol) [19]. Targeting the histone $\mathrm{H} 4$ acetylation sites, due to their associations with active transcription, they identified a series of coordinated gene expression modules across different alcohol exposures and from other environmental stimuli such as heavy metals. Among these modules was a set of genes enriched for ion channels and synaptic proteins. Interestingly, they found genes with alternative splicing known to play a role in alcohol behavior: Dscam and slo [107, 108]. Ghezzi et al. validated slo's role in alcohol tolerance, but Dscam manipulation did not influence the behavior. Importantly, their validation was done using an RNAi knockdown fly line for Dscam which may not have targeted the correct transcript variant [19]. This underscores the importance of transcript variants in alcohol behaviors, and these results remain to be verified in follow-up analyses. This study also found that $\mathrm{H} 4$ acetylation at HDAC genes was occurring in response to tolerance. HDAC6 not only showed increased acetylation, it also showed increased transcript expression across different environmental stressors, with the highest expression in response to heavy metals [19]. Thus, alcohol appears to increase expression of a coordinated network of genes to promote tolerance, and one of these genes coordinates the silencing of other genes.

Sir2, the fly homolog for mammalian Sirt1, is another HDAC gene that has proven important for alcohol sensitivity, conditioned preference, and the development of tolerance $[43,49,51]$. In mammals, Sirt1 in the brain is directly involved in neurogenesis, dendritic morphology, plasticity, regulation of micro RNAs (miRNAs), energy metabolism, and circadian rhythms [132]. It is downregulated following alcohol exposure in the fly $[43,133]$. Alcohol tolerance in the fly depends upon expression of Sir2 in the mushroom body (MB, a neuropil important for learning and memory in the fly [134]) [32, 51, 135]. Engel et al. also demonstrated that the loss of Sir2 disrupted upregulation of approximately $90 \%$ of genes that responded to alcohol exposure [51]. This implies a very different transcriptional landscape without Sir2. Part of the difference was in the expression of pre-synaptic proteins. In order for tolerance to develop synaptic reorganization in the MB needed to occur. This was Sir2 dependent. Taken together, since histone acetylation changes the long-term expression of genes, exposure to alcohol may effect tolerance by altering histone acetylation. Evidence for this model was supported by Adhikari et al. who showed that $H r 38$ expression needs to be terminated by Sir2, which leads to a reduction in $\mathrm{Hr} 38$, which in turn results in an increase in tolerance [136]. $\mathrm{Hr} 38$ is also down-regulated $7 \mathrm{~h}$ following wasp exposure [63], pointing to ongoing silencing of this gene to promote tolerance and alcohol preference. 


\section{Glial affiliated genes}

Glial dysfunction and structural change as a consequence of alcohol consumption have been documented across species $[100,127]$ and glial involvement in alcohol behavior in the fly is not new. Early forward genetics screens showed disruptions in the blood brain barrier (BBB) leading to alcohol resistance [137]. Moody, an orphan G-protein coupled receptor, compromises the BBB due to its role in maintaining tight septate junctions in glial cells. This causes decreased alcohol sensitivity [137]. While Moody has not appeared in genomic survey studies, its regulator, loco, has [44]. Both moody and loco are also important in cocaine sensitivity [137].

Cytoskeletal proteins have also been implicated in glial functioning in response to alcohol, particularly those involved in actin cytoskeleton organization, which are upregulated following alcohol exposure [49]. Recent work has found evidence for actin dysregulation resulting in major topology changes in the perineurial glia (the flies $\mathrm{BBB}$ ) that persist over $24 \mathrm{~h}$, which may be a mechanism that leads to tolerance [122].

In addition to these genes, whole brain analysis has identified a number of other glial related genes that are involved in in alcohol sensitivity and consumption. These include the genes $d r p r, p b l$, and fas [44]. Of particular interest is Draper (drpr), which increases expression in response to glial cell injuries [138]. Draper codes for a cell surface receptor found on ensheathing glia in the adult brain, and is involved in the glial phagocytic response following injury or cellular damage [139]. Draper is also important for synapse reorganization (including in the mushroom body) [140], which is hypothesized to underlie tolerance and alcohol conditioned place preference $[16,106,124,141,142]$. This hypothesis has been supported by the findings in genomic survey studies that identify synaptic signaling and synaptic structural proteins play a role in alcohol behavior [43, 44, 49, 143]. Synaptic reorganization is necessary for the development of tolerance and conditioned place preference in the fly [31, $51,141,142,144]$. Subtle underlying changes in Draper function may make synaptic reorganization, which facilitates behavioral extinction, harder following initial cuereward learning. This may be why Draper appears in GWAS studies but has not appeared in prior transcriptional studies.

The role of glial signaling in alcohol behavior is understudied in the fly and may provide a mechanistic understanding of the role alcohol plays in glial functioning. Recent findings from the mammalian nucleus accumbens using single cell analysis in response to opioids aligns with the hypothesis that glia help shape rewarding memories [145].

\section{Cellular stress genes}

Cellular stress genes present in glia and/or neurons also play a role in alcohol behavior across species [18, 49, 50, $60,126,128,146]$. Genes involved in oxidative stress, heat shock, and unfolded protein responses routinely appear in gene networks for alcohol behavior [128, 147]. Kong et al. found multiple heat shock proteins up-regulated following alcohol exposure. $H s p$ 22, $H s p 70 B a$, Hsp 70Bc, Hsp $70 A a$, Hsp23, Hsp 26, Hsp68, Hsp 27 all show differential expression following alcohol sedation [49]. The stress of a heat shock assay itself can induce tolerance through a hangover gene-dependent pathway [50]. Both heat shock and cold shock show overlapping gene expression with alcohol exposure as well [19]. Previous work also implicated $H s p 70 A a$ as an immediate response gene to alcohol presentation [49]. However, these transcriptional studies were done on whole fly heads. The specific cells in which these genes networks mediate alcohol responses remain unclear.

Genes involved in oxidative stress have also been implicated in alcohol behavior [146, 148]. Most notably the gene $j w a$, which is upregulated in mammals in response to oxidative stress and heat stress [148], is important for the development of tolerance [148]. Other relevant stress response genes implicated in alcohol phenotypes and showing differences in expression levels in response to alcohol are $m s n, M p k 2$ and members of the cytochrome P450 family [19, 44, 49, 53]. These differences in gene expression of heat shock proteins and other cellular response genes (especially for environmental toxins) in response to alcohol exposure may reflect alcohol's cellular toxicity at high doses. Hence, consistent with the glial work described above, increased cellular stress in both glia and neurons facilitate cellular changes that reduce fly sensitivity to alcohol. Indeed, in the case of $m s n$, RNAimediated knockdown of the gene throughout the animal resulted in decreased sensitivity to alcohol's effects on viability [53], but restriction of the knockdown to neuronal populations showed no effect on tolerance [19].

\section{Innate immune response genes}

Innate immune response genes are often found in the same gene networks as cellular stress genes. Multiple studies examining transcriptional changes following alcohol exposure in the fly have found changes in innate immune response genes [49, 143, 149, 150]. Kong et al. found up-regulation of both the Toll and Imd pathways [49]. These pathways converge onto and regulate nuclear factor- $\mathrm{kB}(\mathrm{NF}-\mathrm{\kappa B})$, a critical factor in the innate immune response. A number of these genes are implicated in alcohol sensitivity in other studies as well, including cact, rel, dnr1, dro5, and Spn27A [43, 143, 149]. More recent work on the Toll signaling pathway in alcohol behavior 
demonstrated that reducing the activity of this pathway through mutation or RNAi knockdown increased sensitivity to the sedative effects of alcohol [149]. Increasing Toll pathway activity through overexpression led to decreased sensitivity to alcohol sedation [149]. Activity of the Toll pathway is conserved across species in response to alcohol [147] (reviewed by [151]).

The gene Spn27A is also known to be involved in the innate immune response, where it is upregulated following bacterial infection [152]. It is increased in the fly on the same order of magnitude in response to alcohol [49]. Reduced levels of Spn27A result in increased sensitivity to alcohol, but minimal differences in tolerance [49], similar to the behavioral response seen with manipulations to the Toll pathway [149].

While these genes may not play a role in tolerance, evidence suggests that they may be triggers for the alcohol-based wasp defenses described previously. Innate immune response genes are one category of gene that show increased expression following the shift in alcohol preference in the presence of wasps [63]. Based upon the findings from the Toll pathway, activation of immune pathways in response to wasps is expected to increase resistance of the flies to alcohol, allowing them to sustain themselves on higher alcohol content food without the locomotor or sedating effects of the drug. Increased alcohol concentrations within the fly also prevent bacterial infection. So in the presence of infection, changes in gene expression allow flies to sustain themselves on higher alcohol food.

Brain structure- and circuit-level analysis of gene networks While the mechanistic relationship between these gene networks and changes in alcohol behavior is poorly understood, the fly presents a critical avenue for further research. Many of the components of the networks outlined above were validated through mutant analysis or RNAi-mediated knockdown of targeted genes (for a listing of comprehensive collections of fly mutants, RNAi fly lines, and GAL4 fly lines in which to express RNAi lines, see Table 2). While most have been validated using whole-body mutants or RNAi knockdown in all tissues [19, 44, 45, 49, 53, 150], a number of genes have been validated in neuronal tissue using the elav-GAL4 line [19], in glial tissue using reaper-GAL4 [122], or in even more specific brain structures such as the MB [106] and the ellipsoid body [153]. Utilization of the GAL4/UAS system to validate genes in specific brain structures or circuits is an important advantage of the fly.

There is a long history in the fly of overlap in the genes important for learning/memory, alcohol behavior, and the reward system (reviewed by $[124,154]$ ). One of the first genes discovered to show an alcohol phenotype was amnesiac, already extensively studied for its role in aversive olfactory memory through an MB-dependent circuit [155-157]. The MB plays a role in both tolerance following ethanol exposure and in ethanol-induced hyperactivity in flies [51, 144]. It is also necessary for the expression of alcohol conditioned preference [32], and it functions as a dopaminergic integration center and epicenter for associative learning, particularly in the formation of olfactory memory [134]. The brains of flies only contain approximately 130 dopaminergic neurons, of which a subset panel the MB structure. This dopamine system regulates the flies' reward signaling, short- and long-term memory formation, aversive memory formation, wakefulness, foraging behavior, and oviposition preference [66, 158-164]. Thus, dopaminergic signaling and modulation of the $\mathrm{MB}$ circuit is a crucial component in the development of associative ethanol memories, as well as the encoding of aversive and appetitive ethanol memories [32, 106, 164]. While this work has been primarily accomplished through forward genetic screens, evidence from GWAS studies exists as well. Work by Morozova et al. identified SNPs near the dopamine decarboxylase gene associated with variation in alcohol sensitivity [123]. This implies that underlying differences in dopamine signaling alters alcohol behavior.

As mentioned above, Sir2 expression is required in the $\mathrm{MB}$ for normal alcohol tolerance to develop. Engel et al. demonstrated that Sir2 was important for determining the valence of alcohol and synaptic functioning in the MB [51]. More recent work using alcohol conditioned preference assays points to the actions of Notch signaling within the $\mathrm{MB}$ circuit for mediating long-term alcohol reward memories [106]. Morozova et al. identified members of the Notch signaling pathway involved in alcohol sensitivity [45, 150], and previously Kaun et al. found a role for Scabrous (Sca, a mediator of Notch signaling) in alcohol-associated preference [32]. Upon further exploration of the Notch pathway, Petruccelli et al. found that Notch and Suppressor of Hairless $(\mathrm{Su}(\mathrm{H}))$ signaling mediated by $\mathrm{Sca}$ in the MB is important for long-term alcohol preference [106]. Not only was this pathway important in the adult fly for memory formation, but $\mathrm{Su}(\mathrm{H})$ changes the transcriptional dynamics of the MB. Alternative splicing of $D o p R 2$, a dopamine receptor previously implicated in alcohol behavior [133] and AUD [165], occurs following alcohol exposure driven by $\mathrm{Su}(\mathrm{H})$ activation.

The Jak/Stat Innate immunity pathways also shows extensive crosstalk with the Notch pathway $[166,167]$. Stat $92 E$ was found to be differentially expressed in rejected male flies. One isoform was up-regulated while the other was down-regulated $24 \mathrm{~h}$ post-rejection [71]. Recent work by Petruccelli et al. identified Stat $92 E$ as also 
being alternatively spliced within the $\mathrm{MB}$ following alcohol exposure [106]. Modifications in Stat92E levels due to alcohol exposure in the MB may underlie long-term changes in alcohol preference, as well as larger memory systems involving stress. Other genes involved in innate immune response and cellular stress have also been found in the MB [72]. Further work will need to be done to understand the roles innate immune genes in the $\mathrm{MB}$ play in memory formation.

\section{Caveats and considerations from gene network analysis in fly alcohol behavior}

Studies of alcohol behavior genetics are confounded by the differing modes of alcohol exposure used [16, 44, 123]. If flies consume alcohol from their food source, genes enriched for feeding behavior and alcohol behavior are both enriched [44]. To illustrate, recent work using the DGRP lines have evaluated the overlap between food consumption and alcohol consumption [168]. The authors argue that among the genes associated with alcohol consumption, about $30 \%$ are associated with the caloric nature of alcohol [168]. Additionally, enrichment for olfactory genes is found when animals are exposed to alcohol vapor (either from a food source or air stream) [123]. A number of studies have demonstrated a role for olfactory genes in alcohol sensitivity and tolerance [49, 142, 150, 169]. Lush, one of the most characterized among these genes, encodes an odorant-binding protein known to bind to alcohols [169]. It is down-regulated in response to alcohol and is implicated in alcohol behavior $[43,49])$. Additionally, recent work has shown that synaptic alterations driven by Dunc13 (homolog of mammalian Munc13) in olfactory receptor neurons of the fly play a role in mediating tolerance [142]. Alcohol vapor-induced changes in olfactory genes were addressed by Kong et al., who explained that alcohol is toxic to the antennae cilia causing degeneration of the cilia [49]. Down-regulated olfactory genes are a response to this toxicity, whereas the upregulated olfactory genes may be involved in alcohol behavior. Recent work has also pointed to potential novel roles for olfactory associated genes outside of olfactory receptor neurons [72].

The use of differing modes of alcohol exposure across studies may help explain the lack of significant overlap in their identified genes (excluding functional gene networks which do show overlap). Even across studies using the DGRP lines very few overlapping genes are found. Study methods often differ not only in the mode of alcohol exposure but in length of exposure, concentration, time following exposure, and general experimental design and analysis including the bioinformatics tools used. One of the most surprising examples of this lack of overlap came from Troutwine et al., who used RNA-seq in an attempt to verify innate immune response genes, found by Kong et al. using microarrays [49, 149].

An additional concern is that while both GWAS and transcriptional methods seek to identify genes, the genes identified through GWAS are participating in the predisposition for an alcohol phenotype, whereas transcriptome studies are well-suited to identify changes in response to alcohol. For instance, significance in a GWAS study does not necessarily mean there will be a transcriptional difference in that same gene in response to alcohol. This is why looking at functional and coexpression gene networks may be more appropriate for studying alcohol behavior in the fly. Morozova et al. observed that if they loosened their cutoff accounting for multiple testings they picked up additional gene overlaps with other studies $[16,43]$. If genes are working in coordinated networks and are not changing independent of each other then there should be a reevaluation of how we identify meaningful transcriptional changes.

One additional caveat when considering work done with the DGRP fly lines is that alcohol behavior is sexually dimorphic $[44,170]$. Different SNPs are associated with alcohol behavior depending upon the sex of the fly [44]. Up to this point studies producing transcriptional data have either not found sexual dimorphisms or have not considered them when analyzing data. A number of studies only used male flies, including Morozova et al. [43], Kong et al. [49], Engel et al. [51], and Signor and Nuzhdin [107]. Troutwine et al. used only females [149]. Ghezzi et al. [19] and Urizar et al. [143] used mixed male and female populations. Additional transcriptional work conducted using controlled populations of both males and females must be performed.

\section{Part 3: Future directions}

Morozova et al. elegantly demonstrated that identifying gene networks in the fly could inform human GWAS studies [170]. They used a candidate gene approach in humans for the genes identified in fly networks with homologs. Quantitative Trait Transcript (QTT) analysis for alcohol sensitivity (second exposure) showed a cluster of transcripts involved in metabolic enzyme activity. Centered in the fly network is the gene Men (Malic Enzyme), which has been identified previously in alcohol sensitivity across species [43, 171]. Targeting the human homolog Malic Enzyme (ME1) in the Framingham Heart Cohort showed small yet significant effects of SNPs on cocktail drinking [170]. This demonstrated the utility of identifying gene networks in flies and then using this information to inform the human data. As new gene networks are described, this type of cross species validation will prove insightful. 
Further identification of coordinated gene networks through RNA-seq and ChIP-seq will shed light on larger pathways that could be targets for pharmacological treatment. In 2006 Riley et al. demonstrated that the human homologue of the Drosophila hangover gene is associated with alcohol dependence within an Irish cohort [172]. Both hangover and its human homologue ZNF699 are zinc-finger proteins, making them potential coordinators of gene networks, and thus targets for future drug development. Hangover also plays a role in response to oxidative stress, further implicating the role of cellular stress genes in alcohol behavior [50, 173]. Other potential targets are the proteins regulated by Protein Kinase C (PKC). Recent work demonstrated naltrexone's ability to block alcohol preference in the fly through PKC mechanisms [174]. Previous work implicated the PKC gene inaC in a network of genes associated with tolerance [170]. Both of the fly's genes coding PKCs (InaC and Pkc98E) are also implicated in alcohol sensitivity via the Neuropeptide F (NPF) and serotonin circuits [175].

A gene network approach also illuminates developmental pathways still in use in the adult fly for mediating behavior $[16,32,106]$, which were underappreciated until recently. Additionally, the roles of glia, cellular stress genes, and immune response genes in adult fly behavior are only now being fully realized. Further investigation is needed into the mechanisms that these pathways use to drive alcohol behavior. It is also clear from these genomic surveys that responses to alcohol change over time, both in the genes expressed and in splicing differences [49, 63, 107], which are only now being fully appreciated and will require further investigation.

Recent advances in proteomic research in the fly will also allow researchers to validate expression differences seen at the transcriptome level [176]. Recent proteomic analysis of postmortem human brain tissue of AUD patients showed changes in metabolic, trafficking, cytoskeletal, and excitotoxity proteins [177]. A significant amount of mRNA never becomes protein, so proteomic analysis may be a better method for examining the large number of genes with expression changes [89]. For example, recent work on proteomic changes in the fly brain following olfactory learning implicated the Jak/Stat pathway [176]. Large-scale proteomic studies in the fly will also identify novel networks of proteins associated with alcohol behavior.

\section{Concluding remarks}

In the era of 'Big Data' the fruit fly is an advantageous model organism to use to acquire novel insights into alcohol behavior. Through the use of a broad set of genetic tools, well-characterized behavioral assays, and an ever-growing number of genomic survey studies, one can begin to piece together a mechanistic understanding of the genes involved in alcohol behavior. This work shows translational potential to understand some of the features of AUD in humans. In particular, recent work on learning mechanisms and tolerance in the fly have shown overlap with glial, cellular stress, innate immunity, and chromatin modifying genes in AUD. These gene networks point to a mechanism in which alcohol tolerance and learning is partially mediated through homeostatic mechanisms to deal with cellular injury. Further study of these gene networks in flies may provide a better mechanistic understanding of AUD and drug targets.

\begin{abstract}
Abbreviations
AUD: Alcohol Use Disorder; NESARC: National Epidemiologic Survey on Alcohol and Related Conditions; DSM-5: Diagnostic and Statistical Manual of Mental Disorders, 5th Edition; GWAS: genome-wide association studies; LORR: loss of righting reflex; MET: mean elution time; CAFÉ: capillary feeder; PER: proboscis extension reflex; SNP: single nucleotide polymorphism; HAP1: high alcohol preference mouse line 1; LAP1: low alcohol preference mouse line 1; EGFR: Epidermal Growth Factor Receptor; DGRP: Drosophila Genetics Reference Panel; DSPR: Drosophila Synthetic Population Resource; UAS: upstream activating sequence; TRAP: translating ribosome affinity purification; INTACT : isolation of nuclei tagged in specific cell types; ChIP: chromatin immunoprecipitation; WGCNA: weighted gene coexpression network analysis; HAT: histone acetyltransferase; HDAC: histone deacetylase; miRNA: micro RNA; MB: mushroom body; BBB: blood brain barrier; NF-kB: nuclear factor kappa B; QTT: Quantitative Trait Transcript; PKC: Protein Kinase C.
\end{abstract}

\section{Authors' contributions}

$\mathrm{GE}, \mathrm{KT}, \mathrm{EV}$, and $\mathrm{AC}$ equally contributed to the writing of the manuscript. All authors read and approved the final manuscript.

\section{Author details}

1 Department of Psychological Sciences, Castleton University, Castleton, VT 05735, USA. ${ }^{2}$ Program in Neuroscience, Middlebury College, Middlebury, VT 05753, USA.

\section{Acknowledgements}

We wish to acknowledge Zu Wei Zhai, Rory Kelly, and Joshua Romond for helpful comments on the manuscript.

Competing interests

The authors declare that they have no competing interests.

Availability of data and materials

Not applicable.

Consent for publication

Not applicable.

Ethics approval and consent to participate

Not applicable.

\section{Funding}

Amanda Crocker and Greg Engel are supported by an Institutional Development Award (IDeA) from the National Institute of General Medical Sciences of the National Institutes of Health under Grant Number P20GM103449. The contents of this paper are solely the responsibility of the authors and do not necessarily represent the official views of NIGMS or $\mathrm{NIH}$.

\section{Publisher's Note}

Springer Nature remains neutral with regard to jurisdictional claims in published maps and institutional affiliations. 
Received: 2 October 2018 Accepted: 4 April 2019

Published online: 16 April 2019

\section{References}

1. Alcohol Use Disorder| National Institute on Alcohol Abuse and Alcoholism (NIAAA). https://www.niaaa.nih.gov/alcohol-health/overv iew-alcohol-consumption/alcohol-use-disorders. Accessed 24 Sept 2018

2. Stahre M. Contribution of excessive alcohol consumption to deaths and years of potential life lost in the United States. Prev Chronic Dis. 2014. https ://www.cdc.gov/pcd/issues/2014/13 0293.htm. Accessed 28 Sept 2018.

3. Hasin DS, Grant BF. The national epidemiologic survey on alcohol and related conditions (NESARC) waves 1 and 2: review and summary of findings. Soc Psychiatry Psychiatr Epidemiol. 2015;50:1609-40.

4. American Psychiatric Association. Diagnostic and statistical manual of mental disorders. 5th ed. Washington, DC: American Psychiatric Publishing; 2013 .

5. Tawa EA, Hall SD, Lohoff FW. Overview of the genetics of alcohol use disorder. Alcohol Alcohol. 2016;51:507-14.

6. Prescott CA, Kendler KS. Genetic and environmental contributions to alcohol abuse and dependence in a population-based sample of male twins. Am J Psychiatry. 1999:156:34-40.

7. Heath AC, Bucholz KK, Madden PA, Dinwiddie SH, Slutske WS, Bierut LJ, et al. Genetic and environmental contributions to alcohol dependence risk in a national twin sample: consistency of findings in women and men. Psychol Med. 1997:27:1381-96.

8. Verhulst B, Neale MC, Kendler KS. The heritability of alcohol use disorders: a meta-analysis of twin and adoption studies. Psychol Med. 2015:45:1061-72

9. Farris SP, Arasappan D, Hunicke-Smith S, Harris RA, Mayfield RD. Transcriptome organization for chronic alcohol abuse in human brain. Mol Psychiatry. 2015;20:1438-47.

10. Warden AS, Mayfield RD. Gene expression profiling in the human alcoholic brain. Neuropharmacology. 2017;122:161-74.

11. Nestler EJ. Molecular basis of long-term plasticity underlying addiction. Nat Rev Neurosci. 2001;2:119-28.

12. Korpi ER, den Hollander B, Farooq U, Vashchinkina E, Rajkumar R, Nutt DJ, et al. Mechanisms of action and persistent neuroplasticity by drugs of abuse. Pharmacol Rev. 2015;67:872-1004.

13. Edenberg HJ, Foroud T. Genetics of alcoholism. Handb Clin Neurol. 2014;125:561-71.

14. Edenberg HJ, Foroud T. Genetics and alcoholism. Nat Rev Gastroenterol Hepatol. 2013;10:487-94.

15. Salvatore JE, Han S, Farris SP, Mignogna KM, Miles MF, Agrawal A Beyond genome-wide significance: integrative approaches to the interpretation and extension of GWAS findings for alcohol use disorder. Addict Biol. 2018;24(2):275-89.

16. Morozova TV, Huang W, Pray VA, Whitham T, Anholt RRH, Mackay TFC. Polymorphisms in early neurodevelopmental genes affect natural variation in alcohol sensitivity in adult drosophila. BMC Genomics. 2015;16:865.

17. Farris SP, Miles MF. Ethanol modulation of gene networks: implications for alcoholism. Neurobiol Dis. 2012;45:115-21.

18. Luo J, Xu P, Cao P, Wan H, Lv X, Xu S, et al. Integrating genetic and gene co-expression analysis identifies gene networks involved in alcohol and stress responses. Front Mol Neurosci. 2018. https://doi.org/10.3389/ fnmol.2018.00102/full.

19. Ghezzi A, Krishnan HR, Lew L, lii FJP, Ong DS, Atkinson NS. Alcoholinduced histone acetylation reveals a gene network involved in alcohol tolerance. PLoS Genet. 2013:9:e1003986.

20. Mignogna KM, Bacanu SA, Riley BP, Wolen AR, Miles MF. Cross-species alcohol dependence-associated gene networks: co-analysis of mouse brain gene expression and human genome-wide association data. bioRxiv. 2018:1:380584.

21. Rubin GM, Yandell MD, Wortman JR, Gabor Miklos GL, Nelson CR, Hariharan IK, et al. Comparative genomics of the eukaryotes. Science. 2000;287:2204-15.
22. Fortini ME, Skupski MP, Boguski MS, Hariharan IK. A survey of human disease gene counterparts in the drosophila genome. J Cell Biol. 2000;150:23-30.

23. BDGP: Gene Disruption Project. http://www.fruitfly.org/p_disrupt/index html. Accessed 1 Jan 2019.

24. Kaun KR, Devineni AV, Heberlein U. Drosophila melanogaster as a model to study drug addiction. Hum Genet. 2012;131:959-75.

25. White $\mathrm{BH}$. What genetic model organisms offer the study of behavior and neural circuits. J Neurogenet. 2016:30:54-61.

26. Devineni AV, Heberlein U. The evolution of Drosophila melanogaster as a model for alcohol research. Annu Rev Neurosci. 2013;36:121-38.

27. Devineni AV, Heberlein U. Preferential ethanol consumption in Drosophila models features of addiction. Curr Biol. 2009;19:2126-32.

28. Guarnieri DJ, Heberlein U. Drosophila melanogaster, a genetic model system for alcohol research. Int Rev Neurobiol. 2003;54:199-228.

29. Crabbe JC, Phillips TJ, Belknap JK. The complexity of alcohol drinking: studies in rodent genetic models. Behav Genet. 2010;40:737-50.

30. Devineni AV, McClure KD, Guarnieri DJ, Corl AB, Wolf FW, Eddison M, et al. The genetic relationships between ethanol preference, acute ethanol sensitivity and ethanol tolerance in Drosophila melanogaster. Fly (Austin). 2011;5:191-9.

31. Park A, Ghezzi A, Wijesekera TP, Atkinson NS. Genetics and genomics of alcohol responses in Drosophila. Neuropharmacology. 2017;122:22-35.

32. Kaun KR, Azanchi R, Maung Z, Hirsh J, Heberlein U. A Drosophila model for alcohol reward. Nat Neurosci. 2011;14:612-9.

33. Hendler RA, Ramchandani VA, Gilman J, Hommer DW. Stimulant and sedative effects of alcohol. Curr Top Behav Neurosci. 2013;13:489-509.

34. Karlsson O, Roman E. Dose-dependent effects of alcohol administration on behavioral profiles in the MCSF test. Alcohol. 2016;50:51-6.

35. Wolf FW, Rodan AR, Tsai LT, Heberlein U. High-resolution analysis of ethanol-induced locomotor stimulation in Drosophila. J Neurosci. 2002;22:11035-44.

36. Brabant C, Guarnieri DJ, Quertemont E. Stimulant and motivational effects of alcohol: lessons from rodent and primate models. Pharmacol Biochem Behav. 2014;122:37-52.

37. Pohorecky LA. Biphasic action of ethanol. Biobehav Rev. 1977;1:231-40.

38. Schuckit MA, Smith TL, Trim RS, Allen RC, Fukukura T, Knight EE, et al. A prospective evaluation of how a low level of response to alcohol predicts later heavy drinking and alcohol problems. Am J Drug Alcohol Abuse. 2011:37:479-86.

39. Crabbe JC, Bell RL, Ehlers CL. Human and laboratory rodent low response to alcohol: is better consilience possible? Addict Biol. 2010;15:125-44

40. Cowmeadow RB, Krishnan HR, Atkinson NS. The slowpoke gene is necessary for rapid ethanol tolerance in Drosophila. Alcohol Clin Exp Res. 2005;29:1777-86.

41. Singh CM, Heberlein U. Genetic control of acute ethanol-induced behaviors in Drosophila. Alcohol Clin Exp Res. 2000;24:1127-36.

42. Maples T, Rothenfluh A. A simple way to measure ethanol sensitivity in flies. J Vis Exp. 2011;1:e2541.

43. Morozova TV, Anholt RR, Mackay TF. Transcriptional response to alcohol exposure in Drosophila melanogaster. Genome Biol. 2006;7:R95.

44. Fochler S, Morozova TV, Davis MR, Gearhart AW, Huang W, Mackay TFC, et al. Genetics of alcohol consumption in Drosophila melanogaster. Genes Brain Behav. 2017;16:675-85.

45. Morozova TV, Anholt RR, Mackay TF. Phenotypic and transcriptional response to selection for alcohol sensitivity in Drosophila melanogaster. Genome Biol. 2007;8:R231.

46. Pohl JB, Baldwin BA, Dinh BL, Rahman P, Smerek D, Prado FJ, et al. Ethanol preference in Drosophila melanogaster is driven by its caloric value. Alcohol Clin Exp Res. 2012;36:1903-12

47. Berger KH, Heberlein U, Moore MS. Rapid and chronic: two distinct forms of ethanol tolerance in Drosophila. Alcohol Clin Exp Res. 2004:28:1469-80

48. van Delden W, Kamping A. Genetic variation for oviposition behavior in Drosophila melanogaster. Il. Oviposition preferences and differential survival. Behav Genet. 1990;20:661-73.

49. Kong EC, Allouche L, Chapot PA, Vranizan K, Moore MS, Heberlein U, et al. Ethanol-regulated genes that contribute to ethanol sensitivity and rapid tolerance in Drosophila. Alcohol Clin Exp Res. 2010;34:302-16. 
50. Scholz H, Franz M, Heberlein U. The hangover gene defines a stress pathway required for ethanol tolerance development. Nature. 2005;436:845-7.

51. Engel GL, Marella S, Kaun KR, Wu J, Adhikari P, Kong EC, et al. Sir2/Sirt1 links acute inebriation to presynaptic changes and the development of alcohol tolerance, preference, and reward. J Neurosci. 2016;36:5241-51.

52. Rodan $A R$, Rothenfluh $A$. The genetics of behavioral alcohol responses in Drosophila. In: Reilly MT, Lovinger DM, editors. International review of neurobiology. Cambridge: Academic Press; 2010. p. 25-51.

53. Morozova TV, Hussain Y, McCoy $\sqcup$, Zhirnov EV, Davis MR, Pray VA, et al. A cyclin E centered genetic network contributes to alcohol-induced variation in Drosophila development. Bethesda. 2018;8:2643-53.

54. Ja WW, Carvalho GB, Mak EM, de la Rosa NN, Fang AY, Liong JC, et al. Prandiology of Drosophila and the CAFE assay. Proc Natl Acad Sci USA. 2007;104:8253-6.

55. Moskalev A, Zhikrivetskaya S, Krasnov G, Shaposhnikov M, Proshkina E, Borisoglebsky D, et al. A comparison of the transcriptome of Drosophila melanogaster in response to entomopathogenic fungus, ionizing radiation, starvation and cold shock. BMC Genomics. 2015;16:S8.

56. Cadieu N, Cadieu J-C, El Ghadraoui L, Grimal A, Lambœuf Y. Conditioning to ethanol in the fruit fly - a study using an inhibitor of $\mathrm{ADH}$. $J$ Insect Physiol. 1999;45:579-86.

57. Shiraiwa T, Carlson JR. Proboscis extension response (PER) assay in Drosophila. J Vis Exp. 2007;1:e193.

58. Nunez KM, Azanchi R, Kaun KR. Cue-induced ethanol seeking in Drosophila melanogaster is dose-dependent. Front Physiol. 2018;9:438.

59. Mohammad F, Aryal S, Ho J, Stewart JC, Norman NA, Tan TL, et al. Ancient anxiety pathways influence Drosophila defense behaviors. Curr Biol. 2016;26:981-6.

60. Breese GR, Sinha R, Heilig M. Chronic alcohol neuroadaptation and stress contribute to susceptibility for alcohol craving and relapse. Pharmacol Ther. 2011;129:149-71.

61. Milan NF, Kacsoh BZ, Schlenke TA. Alcohol consumption as selfmedication against blood-borne parasites in the fruit fly. Curr Biol. 2012;22:488-93.

62. Kacsoh BZ, Lynch ZR, Mortimer NT, Schlenke TA. Fruit flies medicate offspring after seeing parasites. Science. 2013;339:947-50.

63. Bozler J, Kacsoh BZ, Chen H, TheurkaufWE, Weng Z, Bosco G. A systems level approach to temporal expression dynamics in Drosophila reveals clusters of long term memory genes. PLoS Genet. 2017;13:e1007054.

64. Marballi K, Genabai NK, Blednov YA, Harris RA, Ponomarev I. Alcohol consumption induces global gene expression changes in VTA dopaminergic neurons. Genes Brain Behav. 2016;15:318-26.

65. Oscar-Berman M, Marinković K. Alcohol: effects on neurobehavioral functions and the brain. Neuropsychol Rev. 2007;17:239-57.

66. Liu Q, Liu S, Kodama L, Driscoll MR, Wu MN. Two dopaminergic neurons signal to the dorsal fan-shaped body to promote wakefulness in Drosophila. Curr Biol. 2012;22:2114-23.

67. Bohnsack JP, Hughes BA, O'Buckley TK, Edokpolor K, Besheer J, Morrow AL. Histone deacetylases mediate GABAA receptor expression, physiology, and behavioral maladaptations in rat models of alcohol dependence. Neuropsychopharmacology. 2018:43:1518-29.

68. Li TK. Pharmacogenetics of responses to alcohol and genes that influence alcohol drinking. J Stud Alcohol. 2000;61:5-12.

69. Schneider A, Ruppert M, Hendrich O, Giang T, Ogueta M, Hampel S, et al. Neuronal basis of innate olfactory attraction to ethanol in Drosophila. PLoS ONE. 2012;7:e52007.

70. Shohat-Ophir G, Kaun KR, Azanchi R, Mohammed H, Heberlein U. Sexual deprivation increases ethanol intake in Drosophila. Science. 2012;335:1351-5.

71. Winbush A, Reed D, Chang PL, Nuzhdin SV, Lyons LC, Arbeitman MN. Identification of gene expression changes associated with longterm memory of courtship rejection in Drosophila males. Bethesda. 2012;2:1437-45.

72. Crocker A, Guan X-J, Murphy CT, Murthy M. Cell type-specific transcriptome analysis in the Drosophila mushroom body reveals memoryrelated changes in gene expression. Cell Rep. 2016;15:1580-96.

73. De Nobrega AK, Noakes EJ, Lyons LC. 0070 SLEEP deprivation exacerbates alcohol-induced toxicity in Drosophila. Sleep. 2017:40:A27.

74. Elmenhorst E-M, Elmenhorst D, Benderoth S, Kroll T, Bauer A, Aeschbach D. Cognitive impairments by alcohol and sleep deprivation indicate trait characteristics and a potential role for adenosine A1 receptors. Proc Natl Acad Sci. 2018;115:8009-14.

75. Long AD, Macdonald SJ, King EG. Dissecting complex traits using the Drosophila synthetic population resource. Trends Genet. 2014:30:488-95.

76. Grenier JK, Arguello JR, Moreira MC, Gottipati S, Mohammed J, Hackett $\mathrm{SR}$, et al. Global diversity lines - a five-continent reference panel of sequenced Drosophila melanogaster strains. Bethesda. 2015;5:593-603.

77. Mackay TFC, Richards S, Stone EA, Barbadilla A, Ayroles JF, Zhu D, et al. The Drosophila melanogaster genetic reference panel. Nature. 2012;482:173-8.

78. dbSNP Summary. https://www.ncbi.nlm.nih.gov/projects/SNP/ snp_summary.cgi?view+summary $=$ view+summary\&build_id $=150$. Accessed 1 Jan 2019.

79. Schumann G, Coin L, Lourdusamy A, Charoen P, Berger KH, Stacey D, et al. Genome-wide association and genetic functional studies identify autism susceptibility candidate 2 gene (AUTS2) in the regulation of alcohol consumption. Proc Natl Acad Sci USA. 2011:108:7119-24.

80. Mulligan MK, Ponomarev I, Hitzemann RJ, Belknap JK, Tabakoff B, Harris RA, et al. Toward understanding the genetics of alcohol drinking through transcriptome meta-analysis. Proc Natl Acad Sci USA. 2006;103:6368-73.

81. Corl AB, Berger KH, Ophir-Shohat G, Gesch J, Simms JA, Bartlett SE, et al. Happyhour, a Ste20 family kinase, implicates EGFR signaling in ethanolinduced behaviors. Cell. 2009:137:949-60

82. King IFG, Eddison M, Kaun KR, Heberlein U. EGFR and FGFR pathways have distinct roles in Drosophila mushroom body development and ethanol-induced behavior. PLoS ONE. 2014;1:9.

83. Ron D, Messing RO. Signaling pathways mediating alcohol effects. Curr Top Behav Neurosci. 2013;13:87-126.

84. Schlegel P, Costa M, Jefferis GS. Learning from connectomics on the fly. Curr Opin Insect Sci. 2017;24:96-105.

85. Costa M, Manton JD, Ostrovsky AD, Prohaska S, Jefferis GSXE. NBLAST: rapid, sensitive comparison of neuronal structure and construction of neuron family databases. Neuron. 2016;91:293-311.

86. Venken KJT, Schulze KL, Haelterman NA, Pan H, He Y, Evans-Holm M, et al. MiMIC: a highly versatile transposon insertion resource for engineering Drosophila melanogaster genes. Nat Methods. 2011;8:737-43.

87. Davie K, Janssens J, Koldere D, Waegeneer MD, Pech U, Kreft $Ł$, et al. A single-cell transcriptome atlas of the aging Drosophila brain. Cell. 2018;174(982-998):e20.

88. Leader DP, Krause SA, Pandit A, Davies SA, Dow JAT. FlyAtlas 2: a new version of the Drosophila melanogaster expression atlas with RNA-Seq, miRNA-Seq and sex-specific data. Nucleic Acids Res. 2018;46:D809-15.

89. Huang W, Carbone MA, Magwire MM, Peiffer JA, Lyman RF, Stone EA, et al. Genetic basis of transcriptome diversity in Drosophila melanogaster. Proc Natl Acad Sci. 2015;112:E6010-9.

90. Brown JB, Boley N, Eisman R, May GE, Stoiber MH, Duff MO, et al. Diversity and dynamics of the Drosophila transcriptome. Nature. 2014;512:393-9.

91. Huang W, Massouras A, Inoue Y, Peiffer J, Ràmia M, Tarone AM, et al. Natural variation in genome architecture among 205 Drosophila melanogaster genetic reference panel lines. Genome Res. 2014;24:1193-208.

92. Harbison ST, Kumar S, Huang W, McCoy LJ, Smith KR, Mackay TFC. Genome-Wide Association Study of Circadian Behavior in Drosophila melanogaster. Behav Genet. 2018;

93. Harbison ST, McCoy LJ, Mackay TFC. Genome-wide association study of sleep in Drosophila melanogaster. BMC Genomics. 2013;14:281.

94. Arya GH, Magwire MM, Huang W, Serrano-Negron YL, Mackay TFC, Anholt RRH. The genetic basis for variation in olfactory behavior in Drosophila melanogaster. Chem Senses. 2015;40:233-43.

95. Garlapow ME, Huang W, Yarboro MT, Peterson KR, Mackay TFC. Quantitative Genetics of Food Intake in Drosophila melanogaster. PLoS ONE. 2015;10:e0138129.

96. Weber AL, Khan GF, Magwire MM, Tabor CL, Mackay TFC, Anholt RRH. Genome-wide association analysis of oxidative stress resistance in Drosophila melanogaster. PLoS ONE. 2012;7:e34745.

97. Zhou Z, Yuan Q, Mash DC, Goldman D. Substance-specific and shared transcription and epigenetic changes in the human hippocampus chronically exposed to cocaine and alcohol. Proc Natl Acad Sci USA. 2011;108:6626-31. 
98. Keil JM, Qalieh A, Kwan KY. Brain transcriptome databases: a user's guide. J Neurosci. 2018;38(10):2399-412.

99. Osterndorff-Kahanek EA, Becker HC, Lopez MF, Farris SP, Tiwari GR, Nunez YO, et al. Chronic ethanol exposure produces time- and brain region-dependent changes in gene coexpression networks. PLoS ONE. 2015;10:e0121522.

100. Zou H, Wang K, Gao Y, Song H, Xie Q, Jin M, et al. Chronic alcohol consumption from adolescence-to-adulthood in mice-hypothalamic gene expression changes in the dilated cardiomyopathy signaling pathway. BMC Neurosci. 2014;15:61.

101. Hawrylycz MJ, Lein ES, Guillozet-Bongaarts AL, Shen EH, Ng L, Miller $J A$, et al. An anatomically comprehensive atlas of the adult human brain transcriptome. Nature. 2012;489:391-9.

102. Hitzemann R, Bottomly D, Darakjian P, Walter N, lancu O, Searles R, et al. Genes, behavior and next-generation RNA sequencing. Genes Brain Behav. 2013;12:1-12.

103. Nunez YO, Truitt JM, Gorini G, Ponomareva ON, Blednov YA, Harris RA, et al. Positively correlated miRNA-mRNA regulatory networks in mouse frontal cortex during early stages of alcohol dependence. BMC Genomics. 2013:14:725.

104. Dykes IM, Emanueli C. Transcriptional and post-transcriptional gene regulation by long non-coding RNA. Genomics Proteomics Bioinform. 2017;15:177-86

105. Lee C, Mayfield RD, Harris RA. Altered gamma-aminobutyric acid type B receptor subunit 1 splicing in alcoholics. Biol Psychiatry. 2014;75:765-73.

106. Petruccelli E, Feyder M, Ledru N, Jaques Y, Anderson E, Kaun KR. Alcohol activates scabrous-notch to influence associated memories. Neuron. 2018;100(1209-1223):e4.

107. Signor S, Nuzhdin S. Dynamic changes in gene expression and alternative splicing mediate the response to acute alcohol exposure in Drosophila melanogaster. Heredity (Edinb). 2018;121:342-60.

108. Krishnan HR, Li X, Ghezzi A, Atkinson NS. A DNA element in the slo gene modulates ethanol tolerance. Alcohol. 2016;51:37-42.

109. Farris SP, Harris RA, Ponomarev I. Epigenetic modulation of brain gene networks for cocaine and alcohol abuse. Front Neurosci. 2015;9:176

110. Vaquero-Garcia J, Barrera A, Gazzara MR, González-Vallinas J, Lahens $N F$, Hogenesch JB, et al. A new view of transcriptome complexity and regulation through the lens of local splicing variations. eLife. 2016;5:e11752.

111. Pfeiffer BD, Jenett A, Hammonds AS, Ngo TB, Misra S, Murphy C, et al. Tools for neuroanatomy and neurogenetics in Drosophila. Proc Natl Acad Sci USA. 2008;105:9715-20.

112. Pfeiffer BD, Ngo TB, Hibbard KL, Murphy C, Jenett A, Truman JW, et al. Refinement of tools for targeted gene expression in Drosophila. Genetics. 2010;186:735-55.

113. Brand AH, Perrimon N. Targeted gene expression as a means of altering cell fates and generating dominant phenotypes. Development. 1993;118:401-15.

114. Kanca O, Bellen HJ, Schnorrer F. Gene tagging strategies to assess protein expression, localization, and function in Drosophila. Genetics. 2017;207:389-412.

115. Thomas A, Lee P-J, Dalton JE, Nomie KJ, Stoica L, Costa-Mattioli M, et al. A versatile method for cell-specific profiling of translated mRNAs in Drosophila. PLoS ONE. 2012;7:e40276.

116. Ma J, Weake VM. Affinity-based isolation of tagged nuclei from Drosophila tissues for gene expression analysis. J Vis Exp. 2014;1:1. https:// doi.org/10.3791/51418.

117. Henry GL, Davis FP, Picard S, Eddy SR. Cell type-specific genomics of Drosophila neurons. Nucleic Acids Res. 2012;40:9691-704.

118. Schauer T, Schwalie PC, Handley A, Margulies CE, Flicek P, Ladurner AG. CAST-ChIP maps cell-type-specific chromatin states in the Drosophila central nervous system. Cell Rep. 2013:5:271-82.

119. Fuller T, Langfelder P, Presson A, Horvath $S$. Review of weighted gene coexpression network analysis. In: Lu HH-S, Schölkopf B, Zhao H, eds. Handbook of Statistical Bioinformatics. Berlin: Springer Berlin Heidelberg; 2011. p. 369-88. https://doi.org/10.1007/978-3-642-16345-6_18. Accessed 1 Jan 2019.
120. Ponomarev I, Wang S, Zhang L, Harris RA, Mayfield RD. Gene coexpression networks in human brain identify epigenetic modifications in alcohol dependence. J Neurosci. 2012:32:1884-97.

121. Handley A, Schauer T, Ladurner AG, Margulies CE. Designing cell-typespecific genome-wide experiments. Mol Cell. 2015;58:621-31.

122. Parkhurst SJ, Adhikari P, Navarrete JS, Legendre A, Manansala M, Wolf FW. Perineurial barrier glia physically respond to alcohol in an Akap200dependent manner to promote tolerance. Cell Rep. 2018;22:1647-56.

123. Morozova TV, Mackay TFC, Anholt RRH. Genetics and genomics of alcohol sensitivity. Mol Genet Genomics. 2014;289:253-69.

124. Robinson BG, Atkinson NS. Is alcoholism learned? Insights from the fruit fly. Curr Opin Neurobiol. 2013;23:529-34.

125. Hayashi T. Conversion of psychological stress into cellular stress response: roles of the sigma-1 receptor in the process. Psychiatry Clin Neurosci. 2015;69:179-91

126. Warden A, Erickson E, Robinson G, Harris RA, Mayfield RD. The neuroimmune transcriptome and alcohol dependence: potential for targeted therapies. Pharmacogenomics. 2016;17:2081-96.

127. Miguel-Hidalgo J. Molecular neuropathology of astrocytes and oligodendrocytes in alcohol use disorders. Front Mol Neurosci. 2018:11:78.

128. Crews FT, Vetreno RP. Neuroimmune basis of alcoholic brain damage. Int Rev Neurobiol. 2014;118:315-57.

129. Jangra A, Sriram CS, Pandey S, Choubey P, Rajput P, Saroha B, et al. Epigenetic modifications, alcoholic brain and potential drug targets. Ann Neurosci. 2016;23:246-60.

130. Maze I, Nestler EJ. The epigenetic landscape of addiction. Ann NY Acad Sci. 2011;1216:99-113.

131. Pinzón JH, Reed AR, Shalaby NA, Buszczak M, Rodan AR, Rothenfluh A. Alcohol-induced behaviors require a subset of Drosophila JmjC-domain histone demethylases in the nervous system. Alcohol Clin Exp Res. 2017:41:2015-24.

132. Ng F, Wijaya L, Tang BL. SIRT1 in the brain — connections with aging-associated disorders and lifespan. Front Cell Neurosci. 2015;9:64.

133. Kong EC, Woo K, Li H, Lebestky T, Mayer N, Sniffen MR, et al. A pair of dopamine neurons target the D1-like dopamine receptor DopR in the central complex to promote ethanol-stimulated locomotion in Drosophila. PLoS ONE. 2010:5:e9954.

134. Aso Y, Hattori D, Yu Y, Johnston RM, lyer NA, Ngo TT, et al. The neuronal architecture of the mushroom body provides a logic for associative learning. eLife. 2014;3:e04577.

135. Xu S, Chan T, Shah V, Zhang S, Pletcher SD, Roman G. The propensity for consuming ethanol in Drosophila requires rutabaga adenylyl cyclase expression within mushroom body neurons. Genes Brain Behav. 2012;11:727-39.

136. Adhikari P, Orozco D, Randhawa H, Wolf FW. Mef2 induction of the immediate early gene $\mathrm{Hr} 38 / \mathrm{Nr} 4 \mathrm{a}$ is terminated by Sirt1 to promote ethanol tolerance. Genes Brain Behav. 2018;18:e12486.

137. Bainton RJ, Tsai LT, Schwabe T, DeSalvo M, Gaul U, Heberlein U. Moody encodes two GPCRs that regulate cocaine behaviors and blood-brain barrier permeability in Drosophila. Cell. 2005:123:145-56.

138. Fullard JF, Baker NE. Signaling by the engulfment receptor draper: a screen in Drosophila melanogaster implicates cytoskeletal regulators, Jun N-terminal Kinase, and Yorkie. Genetics. 2015;199:117-34.

139. Doherty J, Logan MA, Taşdemir OE, Freeman MR. Ensheathing glia function as phagocytes in the adult Drosophila brain. J Neurosci. 2009;29:4768-81.

140. Tasdemir-Yilmaz OE, Freeman MR. Astrocytes engage unique molecular programs to engulf pruned neuronal debris from distinct subsets of neurons. Genes Dev. 2014:28:20-33.

141. Eddison M, Guarnieri DJ, Cheng L, Liu C-H, Moffat KG, Davis G, et al. Arouser reveals a role for synapse number in the regulation of ethanol sensitivity. Neuron. 2011;70:979-90.

142. Xu S, Pany S, Benny K, Tarique K, Hatem O, Gajewski K, et al. Ethanol regulates presynaptic activity and sedation through presynaptic Unc13 proteins in Drosophila. eNeuro. 2018:5:ENEURO.0125-18.2018.

143. Urizar NL, Yang Z, Edenberg HJ, Davis RL. Drosophila homer is required in a small set of neurons including the ellipsoid body for normal ethanol sensitivity and tolerance. J Neurosci. 2007;27:4541-51. 
144. King I, Tsai LT, Pflanz R, Voigt A, Lee S, Jäckle H, et al. Drosophila tao controls mushroom body development and ethanol-stimulated behavior through par-1. J Neurosci. 2011;31:1139-48.

145. Avey D, Sankararaman S, Yim AKY, Barve R, Milbrandt J, Mitra RD. Singlecell RNA-seq uncovers a robust transcriptional response to morphine by Glia. Cell Rep. 2018;24(3619-3629):e4.

146. Teixeira FB, Santana LN, Bezerra FR, Carvalho SD, Fontes-Júnior EA, Prediger RD, et al. Chronic ethanol exposure during adolescence in rats induces motor impairments and cerebral cortex damage associated with oxidative stress. PLOS ONE. 2014;9:e101074.

147. Liu J, Lewohl JM, Harris RA, Iyer VR, Dodd PR, Randall PK, et al. Patterns of gene expression in the frontal cortex discriminate alcoholic from nonalcoholic individuals. Neuropsychopharmacology. 2006;31:1574-82.

148. Li C, Zhao X, Cao X, Chu D, Chen J, Zhou J. The Drosophila homolog of jwa is required for ethanol tolerance. Alcohol Alcohol. 2008;43:529-36.

149. Troutwine BR, Ghezzi A, Pietrzykowski AZ, Atkinson NS. Alcohol resistance in Drosophila is modulated by the Toll innate immune pathway. Genes Brain Behav. 2016;15:382-94.

150. Morozova TV, Mackay TFC, Anholt RRH. Transcriptional networks for alcohol sensitivity in Drosophila melanogaster. Genetics. 2011;187:1193-205

151. Robinson G, Most D, Ferguson LB, Mayfield J, Harris RA, Blednov YA. Neuroimmune pathways in alcohol consumption: evidence from behavioral and genetic studies in rodents and humans. Int Rev Neurobiol. 2014;118:13-39.

152. Gregorio ED, Han S-J, Lee W-J, Baek M-J, Osaki T, Kawabata S-I, et al. An immune-responsive serpin regulates the melanization cascade in Drosophila. Dev Cell. 2002;3:581-92.

153. Ghezzi A, Al-Hasan YM, Krishnan HR, Wang Y, Atkinson NS. Functional mapping of the neuronal substrates for drug tolerance in Drosophila. Behav Genet. 2013:43:227-40.

154. Landayan D, Wolf FW. Shared neurocircuitry underlying feeding and drugs of abuse in Drosophila. Biomed J. 2015;38:496-509.

155. Siegel RW, Hall JC. Conditioned responses in courtship behavior of normal and mutant Drosophila. Proc Natl Acad Sci USA. 1979:76:3430-4.

156. Turrel $\mathrm{O}$, Goguel $\mathrm{V}$, Preat $\mathrm{T}$. amnesiac is required in the adult mushroom body for memory formation. J Neurosci. 2018;38:9202-14.

157. Waddell S, Armstrong JD, Kitamoto T, Kaiser K, Quinn WG. The amnesiac gene product is expressed in two neurons in the Drosophila brain that are critical for memory. Cell. 2000;103:805-13.

158. Yamagata N, Ichinose T, Aso Y, Plaçais P-Y, Friedrich AB, Sima RJ, et al. Distinct dopamine neurons mediate reward signals for short- and longterm memories. Proc Natl Acad Sci USA. 2015;112:578-83.

159. Liu C, Plaçais P-Y, Yamagata N, Pfeiffer BD, Aso Y, Friedrich AB, et al. A subset of dopamine neurons signals reward for odour memory in Drosophila. Nature. 2012;488:512-6.

160. Aso Y, Sitaraman D, Ichinose T, Kaun KR, Vogt K, Belliart-Guérin G, et al. Mushroom body output neurons encode valence and guide memorybased action selection in Drosophila. eLife. 2014;3:e04580.

161. Sun J, Xu AQ, Giraud J, Poppinga H, Riemensperger T, Fiala A, et al. Neural control of startle-induced locomotion by the mushroom bodies and associated neurons in Drosophila. Front Syst Neurosci. 2018;12:6.

162. Sitaraman D, Aso Y, Rubin GM, Nitabach MN. Control of sleep by dopaminergic inputs to the Drosophila mushroom body. Front Neural Circuits. 2015;9:73.

163. Landayan D, Feldman DS, Wolf FW. Satiation state-dependent dopaminergic control of foraging in Drosophila. Sci Rep. 2018;8:5777.

164. Azanchi R, Kaun KR, Heberlein U. Competing dopamine neurons drive oviposition choice for ethanol in Drosophila. Proc Natl Acad Sci USA. 2013:110:21153-8.

165. Trantham-Davidson H, Burnett EJ, Gass JT, Lopez MF, Mulholland PJ, Centanni SW, et al. Chronic alcohol disrupts dopamine receptor activity and the cognitive function of the medial prefrontal cortex. J Neurosci. 2014;34:3706-18

166. Flaherty MS, Zavadil J, Ekas LA, Bach EA. Genome-wide expression profiling in the Drosophila eye reveals unexpected repression of notch signaling by the JAK/STAT pathway. Dev Dyn. 2009;238:2235-53.

167. Jin S, Mutvei AP, Chivukula IV, Andersson ER, Ramsköld D, Sandberg R, et al. Non-canonical Notch signaling activates IL-6/JAK/STAT signaling in breast tumor cells and is controlled by p53 and IKKa/IKK 3 . Oncogene 2013:32:4892-902.
168. Sekhon ML, Lamina O, Hogan KE, Kliethermes CL. Common genes regulate food and ethanol intake in Drosophila. Alcohol. 2016;53:27-34.

169. Kim MS, Repp A, Smith DP. LUSH odorant-binding protein mediates chemosensory responses to alcohols in Drosophila melanogaster. Genetics. 1998;150:711-21.

170. Morozova TV, Ayroles JF, Jordan KW, Duncan LH, Carbone MA, Lyman $\mathrm{RF}$, et al. Alcohol sensitivity in Drosophila: translational potential of systems genetics. Genetics. 2009;183:733-45.

171. Yin H-O, Kim M, Kim J-H, Kong G, Kang K-S, Kim H-L, et al. Differential gene expression and lipid metabolism in fatty liver induced by acute ethanol treatment in mice. Toxicol Appl Pharmacol. 2007;223:225-33.

172. Riley BP, Kalsi G, Kuo P-H, Vladimirov V, Thiselton DL, Vittum J, et al. Alcohol dependence is associated with the ZNF699 gene, a human locus related to Drosophila hangover, in the Irish Affected Sib pair study of alcohol dependence (IASPSAD) sample. Mol Psychiatry. 2006;11:1025-31.

173. Schwenkert I, Eltrop R, Funk N, Steinert JR, Schuster CM, Scholz H. The hangover gene negatively regulates bouton addition at the Drosophila neuromuscular junction. Mech Dev. 2008;125:700-11.

174. Koyyada R, Latchooman N, Jonaitis J, Ayoub SS, Corcoran O, Casalotti SO. Naltrexone reverses ethanol preference and protein kinase $\mathrm{C}$ activation in Drosophila melanogaster. Front Physiol. 2018;9:175.

175. Chen J, Zhang Y, Shen P. A protein kinase C activity localized to neuropeptide Y-like neurons mediates ethanol intoxication in Drosophila melanogaster. Neuroscience. 2008;156:42-7.

176. Zhang Y, Shan B, Boyle M, Liu J, Liao L, Xu T, et al. Brain proteome changes induced by olfactory learning in Drosophila. J Proteome Res. 2014;13(8):3763-70.

177. Enculescu C, Kerr ED, Yeo BKY, Dodd PR, Schenk G, Fortes MRS, et al. Proteomics reveals profound metabolic changes in the alcohol use disorder brain. bioRxiv. 2018;1:447912.

178. Gramates LS, Marygold SJ, dos Santos G, Urbano J-M, Antonazzo G, Matthews BB, et al. FlyBase at 25: looking to the future. Nucleic Acids Res. 2017;45:663-71.

179. Miller, Robinson KJ, Cleary MD, Doe CQ, Doe CQ. TU-tagging: cell type-specific RNA isolation from intact complex tissues. Nat Methods. 2009;6:439-41.

180. Hida N, Aboukilila MY, Burow DA, Paul R, Greenberg MM, Fazio M, et al. EC-tagging allows cell type-specific RNA analysis. Nucleic Acids Res. 2017:45:e138.

181. Abed M, Kenyagin-Karsenti D, Boico O, Orian A. DamID: a methylationbased chromatin profiling approach. In: Collas P, ed. Chromatin immunoprecipitation assays: methods and protocols. Totowa: Humana Press; 2009. p. 155-69. https://doi.org/10.1007/978-1-60327-414-2_11.

182. Dietzl G, Chen D, Schnorrer F, Su K-C, Barinova Y, Fellner M, et al. A genome-wide transgenic RNAi library for conditional gene inactivation in Drosophila. Nature. 2007:448:151-6.

183. Perkins LA, Holderbaum L, Tao R, Hu Y, Sopko R, McCall K, et al. The transgenic RNAi project at harvard medical school: resources and validation. Genetics. 2015;201:843-52.

184. Jenett A, Rubin GM, Ngo TB, Shepherd D, Murphy C, Dionne H, et al. A GAL4-driver line resource for Drosophila neurobiology. Cell Rep. 2012:2:991-1001.

185. The modENCODE Consortium, Roy S, Ernst J, Kharchenko PV, Kheradpour $\mathrm{P}, \mathrm{Negre} \mathrm{N}$, et al. Identification of functional elements and regulatory circuits by Drosophila modENCODE. Science. 2010;330:1787-97.

186. Aibar S, González-Blas CB, Moerman T, Huynh-Thu VA, Imrichova H, Hulselmans G, et al. SCENIC: single-cell regulatory network inference and clustering. Nat Methods. 2017;14:1083-6.

187. Ashburner M, Ball CA, Blake JA, Botstein D, Butler H, Cherry JM, et al. Gene ontology: tool for the unification of biology. The gene ontology consortium. Nat Genet. 2000;25:25-9.

188. The Gene Ontology Consortium. Expansion of the gene ontology knowledgebase and resources. Nucleic Acids Res. 2017:45:D331-8.

189. Huang DW, Sherman BT, Lempicki RA. Systematic and integrative analysis of large gene lists using DAVID bioinformatics resources. Nat Protoc. 2009;4:44-57

190. Huang DW, Sherman BT, Lempicki RA. Bioinformatics enrichment tools: paths toward the comprehensive functional analysis of large gene lists. Nucleic Acids Res. 2009;37:1-13. 
191. Bailey TL, Boden M, Buske FA, Frith M, Grant CE, Clementi L, et al. MEME Suite: tools for motif discovery and searching. Nucleic Acids Res. 2009;37:W202-8.

192. Zhang B, Horvath S. A General framework for weighted gene co-expression network analysis. Statistical applications in genetics and molecular biology. 2005;4. https://www.degruyter.com/view/j/sagmb.2005.4.issue -1/sagmb.2005.4.1.1128/sagmb.2005.4.1.1128.xml. Accessed $3 \mathrm{Mar}$ 2019 .

193. Fabregat A, Jupe S, Matthews L, Sidiropoulos K, Gillespie M, Garapat $P$, et al. The reactome pathway knowledgebase. Nucleic Acids Res. 2018:46:D649-55.
194. Cline MS, Smoot M, Cerami E, Kuchinsky A, Landys N, Workman C, et al. Integration of biological networks and gene expression data using cytoscape. Nat Protoc. 2007;2:2366-82.

195. Baker EJ, Jay JJ, Bubier JA, Langston MA, Chesler EJ. GeneWeaver: a web-based system for integrative functional genomics. Nucleic Acids Res. 2012;40:D1067-76.
Ready to submit your research? Choose BMC and benefit from:

- fast, convenient online submission

- thorough peer review by experienced researchers in your field

- rapid publication on acceptance

- support for research data, including large and complex data types

- gold Open Access which fosters wider collaboration and increased citations

- maximum visibility for your research: over $100 \mathrm{M}$ website views per year

At BMC, research is always in progress.

Learn more biomedcentral.com/submissions 